可視化情報 Vol. 10 Suppl. No. 2（1990年11月）

A112 三次元壁面噴流の縦渦とエントレインメントの可視化

$\begin{array}{lll}\text { 九大·機能研 } & \text { 高曾 } & \text { 微 } \\ \text { 九大·院 } & \text { 長沢 } & \text { 聖 } \\ \text { 九大·機能研 } & \text { 速水 } & \text { 洋 }\end{array}$

\title{
Visualization of Streamwise Vortices and Entrainment in a Coflowing Three-Dimensional Wall Jet
}

Tōru KŌSO*, Sei NAGASAWA** and Hiroshi HAYAMI*

\begin{abstract}
A circular turbulent jet issued along a plane wall is visualized by means of laser-induced fluorescence to investigate the large-scale structure in the fully devloped region of jet.The fluorescence dye was premixed to jet fluid, and a cross section normal to jet axis was illuminated by a thin laser sheet. To observe the evolution of jet fluid pattern, the laser sheet was moved to follow the flow strucure. And a surrounding fluid was marked by deeper fluorescence dye and process of the entrainment and the mixing with jet fluid were observed. The results indicate that the structure of the jet is characterized by three-dimensional large-scale vortices and that the flow is filled with numerous streamwise vortices. A pair of large-scale secondary flow which entrain the fluid from upper region and push to lateralward is found to exert an important effect on the entrainment of surrounding fluid, and appear to play a dominant role on the greater lateral rate of spread.
\end{abstract}

\section{1.まえがき}

平板壁に沿って平行に円形噴流を噴出させた三次元壁面噴流は、壁面に垂直な方向（y 方向）には壁面噴流の速度分布で、横方向（ $\mathrm{z}$ 方向）には自由噴流の速度分布を有する。 この流れは工学的には翼面上の境界層制御、ガスタービン翼の膜冷却、自動車トンネル出 口での排ガス应散などに見られ、これまでに多くの研究がなされてきた(1) (12)。その結 果、流れは壁面上をはうように横方向へ極めて大きく应大することが明らかになた。また このような拡大は、乱れが壁面によって抑制されて生じる非等方乱れ(6)、(7)や非等方な乱 流間欠性(5)および乱流二次流れ“11)によって生しると推測されている。しかし従来の可視 化(2)(4)(13)では平均的な流れが観測されているだけで、詳細な構造は明らかでない。

そこで本研究では、レーザー誘起蛍光法を用いて噴流の種々の断面を可視化して大規模 渦、特に維瀜の構造と挙動について調べた。また観测断面を大規摸構造の流下速度と同速 度で移動させて観察し、二次流れおよびエントレインメントの様子について詳しく検討し た。

* Institute of Advanced Material Study, Kyushu University 86, 6-1, Kasuga-koen, Kasuga 816.

**Interdisciplinary Graduate School of Engineering Sciences, Kyushu University. 


\section{2、実験装置および方法}

Fig. 1 に本実験で用いた可視化用水槽 ${ }^{(14)}$ の概略困を示す。断面 $250 \mathrm{~mm} \times 250 \mathrm{~mm}$ の透明ア クリル製のダクトの中にアクリル平板を置き、 平板壁に沿って直径 $\mathrm{d}=9.4 \mathrm{~mm}$ の円管から噴 流を平行に噴出させた。ダクト断面には一侎 流が流れており、無限に広い一様流中の三次 元壁面噴流を模擬している。噴出流体には蛍 光染料フルオレセインナトリウムを微量混入 して噴流を可視化した。水槽の下流端も透明 アクリル板製で、噴流は下流側からも観察で きる。

普通の照明によって噴流の外形を観察する と共に、レーザーシート光を照射して噴流の 断面を可視化した。Fig.2(a)に噴流軸を含む 断面の撮影方法を示し、Fig.2(b)に噴流軸に 垂直な断面の撮影方法を示す。噴流にレーザ ーシート光を照射するとシート光面上のフル オレセインナトリウム水溶液が蛍光を発し、 噴出流体が可視化される。このフルオレセイ ンナトリウム水溶液は光の透過を比較的さま たげず、レーザー光で発光した蛍光による周 囲の染料の発光も比較的少ないため、噴流内 部の複雑な構造を観察するのに適している。

またフルオレセイントトリウムの励起光ス ペクトルのピークは約 $490 \mathrm{~nm}$ 、虽光スペクトル ピークは約520nm (15)であるから、レーザー 光源はアルゴンイオンレーザー (SP2016-05s) シングルモードの波長488nm を用い、蛍光の 撮影には波長500nm.以下を完全にカットする 光学フィルタ (HOYA Y-52) を通して壁面散乱 光などを遮断した。撮影には白黒C C Dカメ ラ（松下WV-CD20）を用いてVTRに録画し、 ビデオプリント出力した。

レーザーシート光の厚さは䄪0. $5 \mathrm{~mm}$ で、レー ザー光を光ファイバーでシリンドリカルレン

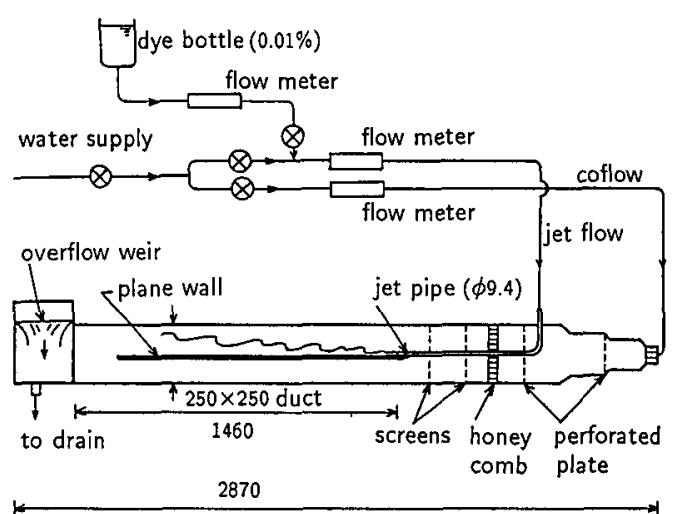

Fig. 1 Water tunnel

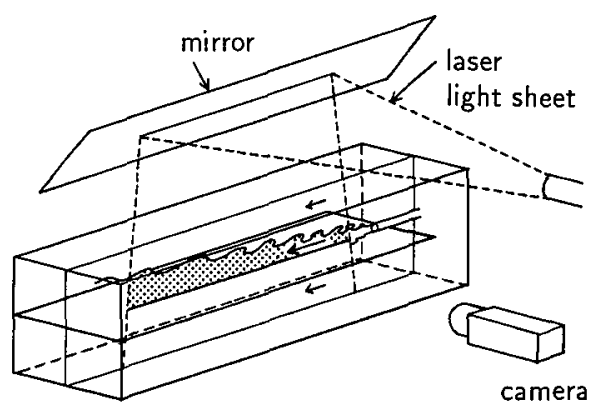

(a) Cross section along jet axis

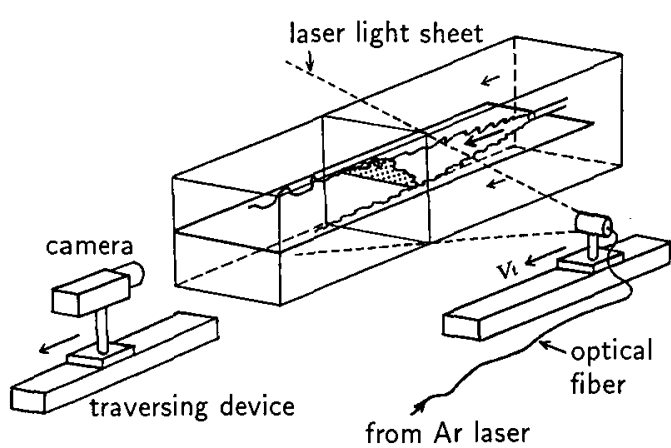

(b) Cross section normal to jet axis

Fig. 2 Optics to illuminate the cross sections of jet 
ズへ導き作成した。また、レーザーシート光およびカメラを走行させるためパルスモータ 駆動のトラバース装置を用いた。

実験は噴流速度 $\mathrm{u}_{\mathrm{j}}=0.15 \mathrm{~m} / \mathrm{s}$ 、一様平行流速 $\mathrm{u}_{\mathrm{\theta}}=0.015 \mathrm{~m} / \mathrm{s}$ で行った。速度比は $\mathrm{u}_{\odot} /$ $u_{j}=0.1$ で噴出レイノルズ数は $R e_{j}=\left(u_{j}-u_{\bullet}\right) d / \nu \leftrightharpoons 1700$ である。また、噴出流

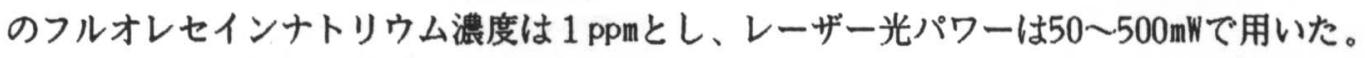

\section{3. 実験結果および考察}

\section{1 外形の可視化}

Fig. 3 に噴流の外形の可視化画像を示す。 この画像は噴流の瞬間的な濃度分布を示して いる。(a)の平面画像は(b)の側面画像より大 きく拡がっており三次元壁面噴流の特徵が明 瞭に現れている。なお、本論文に示す全ての 画像の撮像時間は33.3ms (ビデオ1フレーム) て、瞬間的なパターンを示している。

3. 2 断面の可視化

Fig. 4 に噴流軸を含む断面の可視化画像を 示す。周囲流体（画像の黒い部分）の大きな 塊が噴流中心まで達しており、噴流幅と同程 度のスケールの運動が生じていることがわか る。またFig. 4 (b) 加ら、中心から周囲へ向か って後ろに傾いた巻き込み構造が見られる。 なお、これらの大規模構造が下流へ流れてい く際のパターンの変化はかなりゆるやかであ つた。

Fig. 5 に噴流軸に垂直な断面画像を示す。 $\mathrm{x} / \mathrm{d}=1 て ゙ 円$ 形であったものが、 $\mathrm{x} / \mathrm{d}=10$ 程度で 乱流摆移し周囲流体と混合していく様子がよ くわかる。 $\mathrm{x} / \mathrm{d}=30$ 程度までは噴流の搪がりは 壁面垂直方向、横方向に同程度であるが、 $\mathrm{x}$ $/ \mathrm{d}=50$ 以上では横方向への拡大が顕著になる。 また断面内の構造のスケールは噴流幅の增大 に対応して大きくなることが観察される。さ らに、これらの画像と噴流軸を含む断面形状 （Fig.4）を孝え合わせると、この流れの構造 は強い三次元性を有していることがわかる。 なお、これらの画像は非等方な桩大は別とし

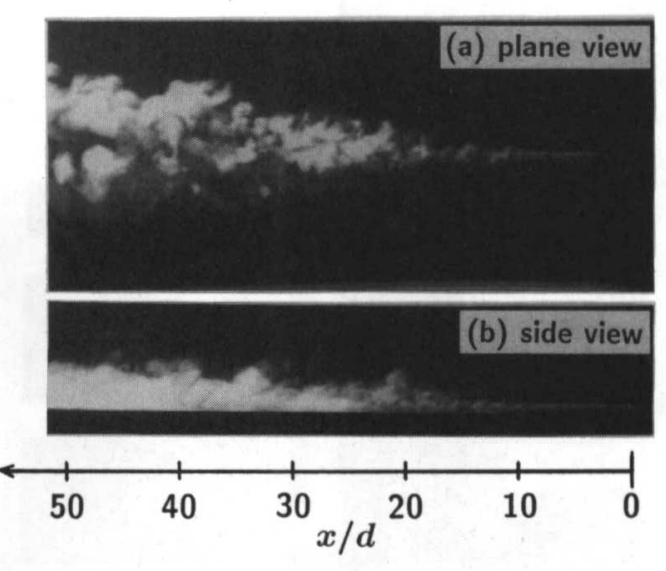

Fig. 3 Classic picture of a coflowing three-dimensional wall jet

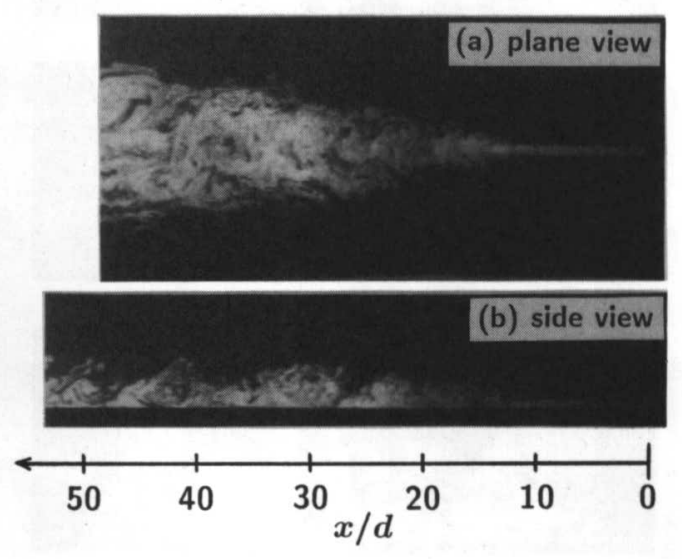

Fig. 4 Cross sections along jet axis 

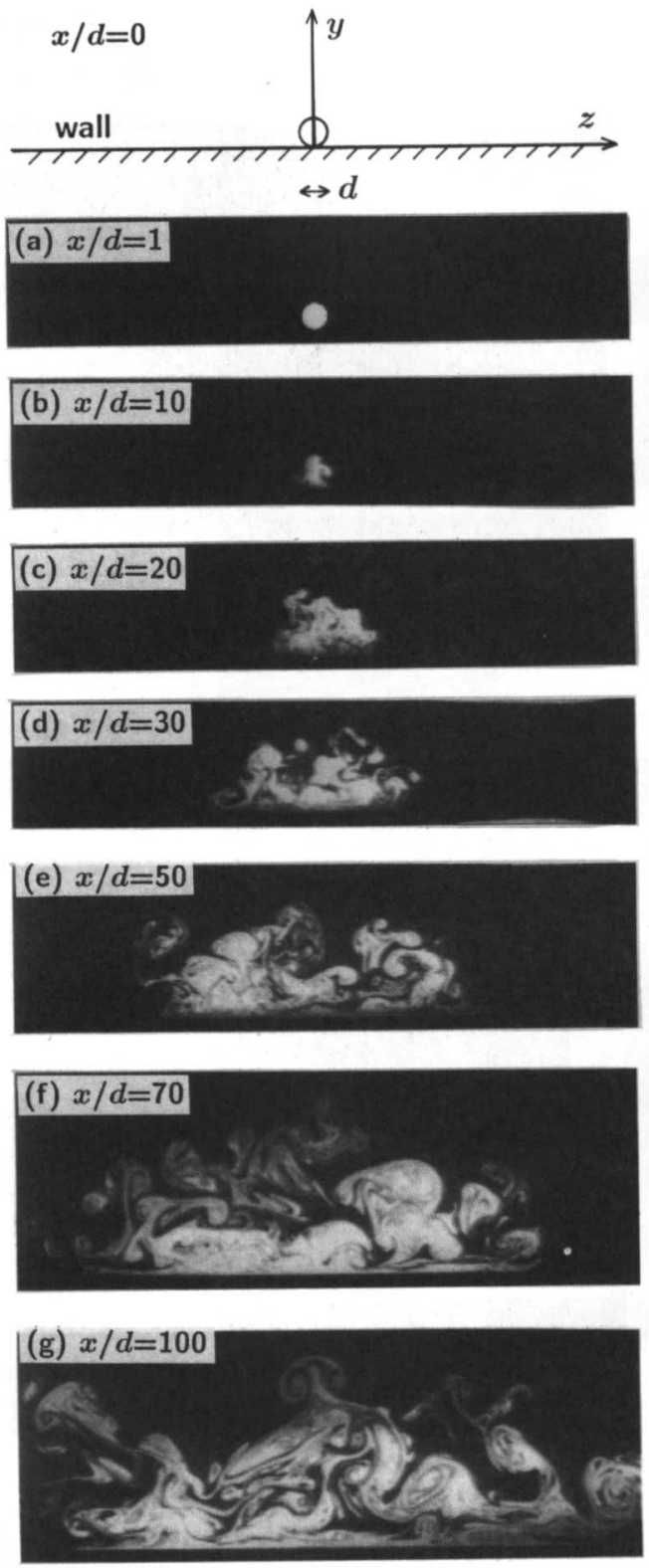

Fig. 5 Cross sections normal to jet axis
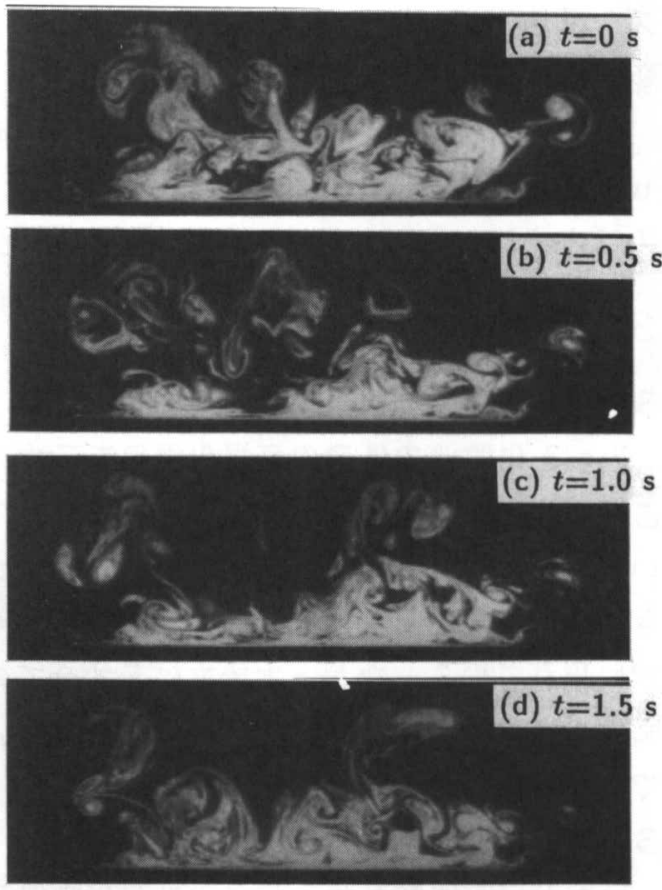

Fig. 6 Temporal variation of pattern in a cross section at $x / d=70$
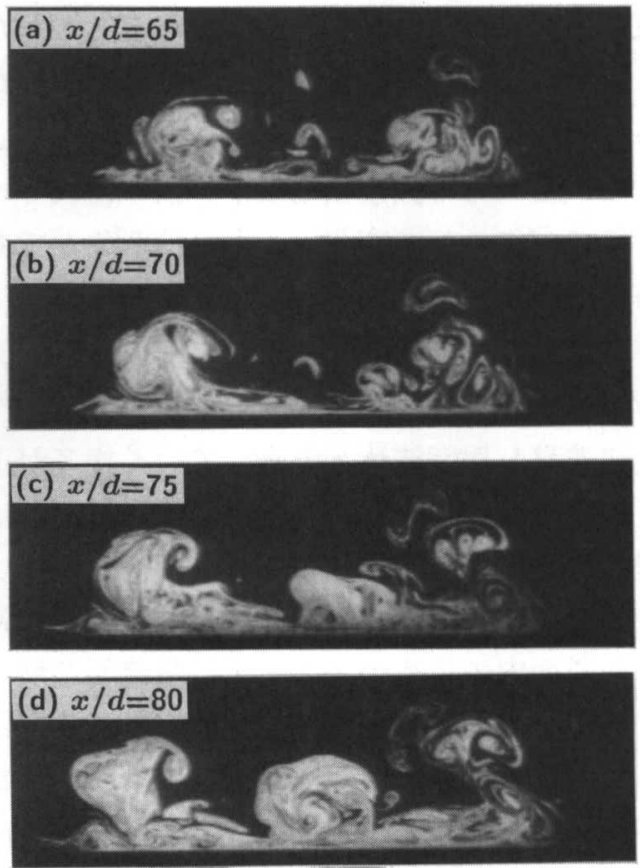

Fig. 7 Transformation of pattern in a cross sectional frame moving with flow 
て、円形噴流(14)(16) の可視化写真と同様な傾向を示している。

Fig. 6 に十分発達した領域 $(x / d=70)$ における噴流断面形状の時間的変化を示す。(a) (d)の画像は激しく変化しているが、流れ方向に軸を持った縦渦による巻込みパターンが数 多く見られる。特にキノコ断面のような形は回転方向の異なる縦渦が対をなしたものであ り、U字形に曲がったヘアピン状の渦系対構造の断面と考えることができる。このような 渦系対構造は、はじめ渦輪などの周方向渦系要素であったものが高次の不安定性などによ って変形を受けたり、平均速度差によって流れ方向に引き伸ばされたりして生じたと考え ることができる。

\section{3 走行レーザーシートによる二次流れの可視化}

大規模構造が流下する際に変形する様子を調べるため、レーザーシート光を大規模構造 の流下速度と同程度の速度で走行させて観察した。その際、大規模構造の流下速度は断面 内で一粎ではないので周辺部の構造に着目してその流下速度で走行させた。なお、流下速 度は時間的にも変動するが、レーザーシート光の走行速度は一定とした。

Fig. 7にx/d=65 80の間で、断面形状の変形をレーザーシート走行速度 $\mathrm{V}_{t}=0.021 \mathrm{~m} / \mathrm{s} て ゙$ 追跡した画像を示す。この連続画像から画面右側に反時計回りの旋回流れ、左側に時計回 りの旋回流れを観察することができる。このような二次流れの存在は選択的シーディング したLDA(1)によっても観测されており、Launderら(11)によって指摘された乱流二次流 れに対応するものと考えられる。また、この旋回する二次流れは中央上部から内向きに流 体を取り込み横へ流出させるので、三次元壁 面噴流の横方向への拡大に大きな役割を果た しているものと考えられる。なお、この二次 流れは固定断面では観測できず、観測断面を 走行させてはじめて観察された。

3. 4 エントレインメントの可視化

周囲の流体が噴流内部に取り込まれる様子 を観察するため周囲の一点から比較的高濃度 (500ppm)のフルオレセインナトリウムを連続 的に混入して観察した。高濃度のフルオレセ インナトリウムの蛍光は極めて明るいので噴 流内部に取り込まれて混合した後もその輝度 から噴出流体と区別することが出来る。この 場合も大規模構造の流下速度と同程度の速度 でレーザーシート光を走行させて周囲に混入 した染料を追跡した。

Fig. 8に断面中央の上部の一様流に注入し た例を示す。明るい部分が一様流の一点から 注入したマーカーで、比較的暗い部分が噴出
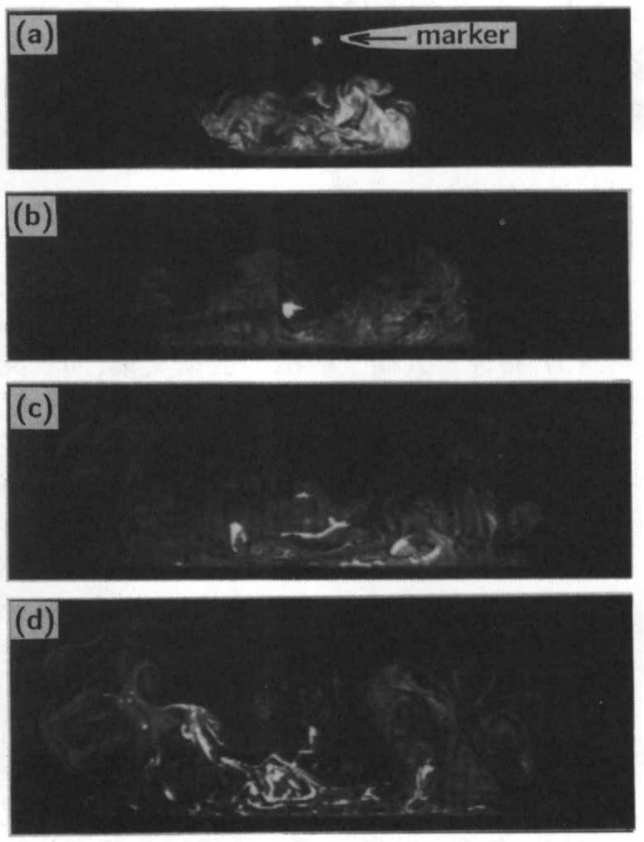

Fig. 8 Entrainment of surrounding fluid in plane of symmetry. $\quad$ (a) $x / d=30$, (b) $x / d=50$, (c) $x / d=70$, (d) $x / d=100$ 
流体である。下流へ流れるに従って大規模渦 に巻き込まれ噴出流体と混合する様子が観察 できる。この場合比較的速く噴流断面全域に 混合している。Fig. 9に噴流の右横上部の一 様流に混入した例を示す。この場合は周辺部 の縦渦の巻き込み運動によって噴流内部に取 り込まれるが、旋回二次流れのため噴流の右 半分の領域内で混合が進んでいる。

\section{4.あとがき}

三次元壁面噴流の断面の可視化から、十分 発達した噴流の構造は極めて三次元性が強く、 洞系対などの縦渦が噴流内を埋めつくす程に 存在しいることが明らかになった。またレー ザーシート光を大規模構造の流下速度と同速 度で走行させて観察したところ、噴流内には 一対の大きな旋回する二次流れが存在してい ることが明らかになった。この二次流れはエ ントレインメントに影響を及ぼしており、三 次元壁面噴流の横方向への拡大にも大きな役
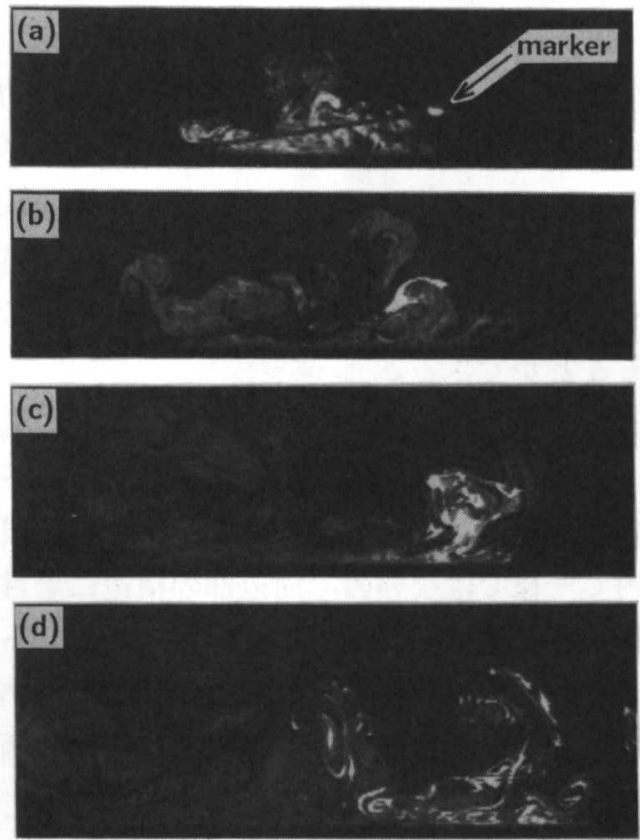

Fig. 9 Entrainment of surrounding fluid in off-center region. $\quad$ (a) $x / d=30$, (b) $x / d=50$, (c) $x / d=70$, (d) $x / d=100$ 割を果たしているものと考えられる。

\section{参考文献}

(1) 高曾・末吉·速水、第21回乱流シンポジウム(1989), 250.

(2) Newman, B. G. , Patel, R. P. , Savage, S. B. andT jio, H. K. , Aeronaut. Q. , 23-4 (1971) , 188.

(3) 高曾·大橋、機械学会論文集、44-380(1978), 1266.

(4) 高曾·大橋、機械学会論文集、47-418B(1981), 1002.

(5) 高曾·大橋、機械学会論文集、47-421B(1981), 1715 .

(6) Davis, M. R. and Winarto, H. , J. Fluid Mech. , 101(1980), 201.

(7) Fujisawa, N. andShirai, H. , Trans. JSASS 32-95(1989), 35.

（8）奄本·加藤、機械学会講演論文集、No. 750-16(1975)，209.

(9) Rajaratnam, N. andStalker, M. J., ASCEJ. HydraulicsDiv. 108-HY2(1982), 187.

(10) 山田 · 中村 · 山下 · 矢野、機械学会論文集、52-474B(1986), 740.

(11) Launder, B. E. andRodi, W. , Ann. Rev. Fluid Mech. , 15(1983), 429.

(12) 飯田・松田、機械学会論文集、54-498B(1988), 354.

(13) 高曾·大橋、第 8 回流れの可視化シンボジウム $(1980), 147$.

流れの可視化学会、新版流れの可視化ハンドブック，朝倉書店(1986), 171.

（14）高曾·岡留、流れの可視化写真集7(1990), 24.

（15）吉田 ·田城、流れの可視化, 4-14(1984), 13.

(16) Dimotakis, P. E. , Miake-Lye, R. C. andPapantoniou, D. A. , Phys. Fluids, 26-11 (1983), 3185. 